\title{
Perceptions of Vermi Raisers on Different Vermicomposting Practices Adopted in Zamboanga Del Sur, Philippines
}

\author{
Jeffrey P. Villaver ${ }^{1}$, Renante A. Panlaan ${ }^{2}$, Moises Glenn G. Tangalin ${ }^{3}$ \\ ${ }^{I}$ College of Agriculture, Zamboanga del Sur Provincial Government College \\ Aurora, Zamboanga del Sur, Philippines \\ ${ }^{2}$ College of Agriculture, ${ }^{3}$ Research and Extension Office \\ J.H. Cerilles State College - Dumingag Campus, Dumingag, Zambonga del Sur
}

\begin{abstract}
Vermi plays an important role in improving soil fertility and structure. This study was conducted to find out the perceptions of vermi raisers on different vermicomposting practices adopted in Zamboanga del Sur, Philippines. The researchers utilized the descriptive method in gathering the necessary data. Results revealed that the combination of 60\% rice straw, 5\% kakawate, and 35\% manure is the most preferred feeding materials. The respondents also revealed that the 5\% inclusion rate of jackfruit, banana, and pineapple peelings in the bedding materials increases the vermi population as compared to pure rice straw, kakawate, and manure. The higher cost of inputs and labor and pest invasion are the two most encountered problems. Covering the bed with canvass or galvanized iron, follow the correct procedure in the pre-decomposition process, and seek assistance from the agriculturists are the three most effective practiced solutions. The findings showed that the population of vermi can be doubled with the inclusion of jackfruit, banana and pineapple peelings in the substrate. Moreover, the harvest time is reduced due to higher consumption level. Vermicomposting is very necessary to answer the increasing demand for organic fertilizer amidst climate change.
\end{abstract}

Keywords: feeding materials, perceptions, Philippines, practices, vermicomposting

\section{INTRODUCTION}

The major problems that our country faces today are lower production of agricultural products and the high cost of production inputs (R. Singh, Kapoor, \& Kumar, 2012). The trend towards modernization such as hybridization and intensive application of synthetic fertilizers \& chemicals to different agricultural crops degrade the environment and deplete the natural resources as well (Carvalho, 2017). However, environmental problems such as global warming, lower production, and infertility of the soil can be healed through the continuous use of organic fertilizers such as compost, vermicast or any farm manures (Satchell, 2012).

Vermiculture is one of the most promising technologies to answer the demand of people who used organic fertilizer. Vermicomposting is the process of producing compost with the aid of vermi (Aalok, Tripathi, \& Soni, 2008). Vermicast or worm poop is the excreta of earthworm consists more amount of NPK compared to an ordinary soil (Karmegam \& Daniel, 2009). Vermicompost is a very potential organic fertilizer for crop production (Guerrero III, 2010).

Soil fertility is not a serious problem today if all farmers are inclined to adopt organic farming (Altieri $\&$ Koohafkan, 2008). If organic materials are added in the field, indigenous microorganisms will multiply (Sharma et al., 2014) and at the same time, release its enzymes and nutrients for sustainable crop production (S. Singh \& Nain, 2014). Vermiculture plays an important role in maintaining the cleanliness of the surroundings, reduces trash, reduces air pollution, digests organic matter, and recycles organic waste materials (Adorada, 2008).

Vermiculture is one of the technologies introduced by the Department of Science and Technology (DOST), Department of Agriculture (DA), Bureau of Soil and Water Management (BSWM), and some Local Government Units (LGU) in the Province of Zamboanga del Sur. The vermi (African Night Crawler) is given to some interested farmers for free by the government agencies and politicians. Benchmarking of vermicomposting practices is the main focus of this research. The results and findings would be used as a pattern for sustaining the vermicomposting project in Zamboanga del Sur, Philippines. 


\section{MATERIALS AND METHODS}

The researchers utilized the descriptive survey method in gathering data and information to accomplish the purpose of this research. A total of 47 successful vermi raisers in Zamboanga del Sur were the respondents of the study. The questionnaire was prepared as an instrument for data collection. The study was conducted in the nine (9) selected municipalities in Zamboanga del Sur. All of the respondents were interviewed to determine their actual practices in sustaining the vermicomposting project. Pictures were taken during the interview as additional evidence. Figure 1 shows the exact location where the survey conducted. Data were analysed using frequency counts, percentage, weighted arithmetic means (WAM) and rank.

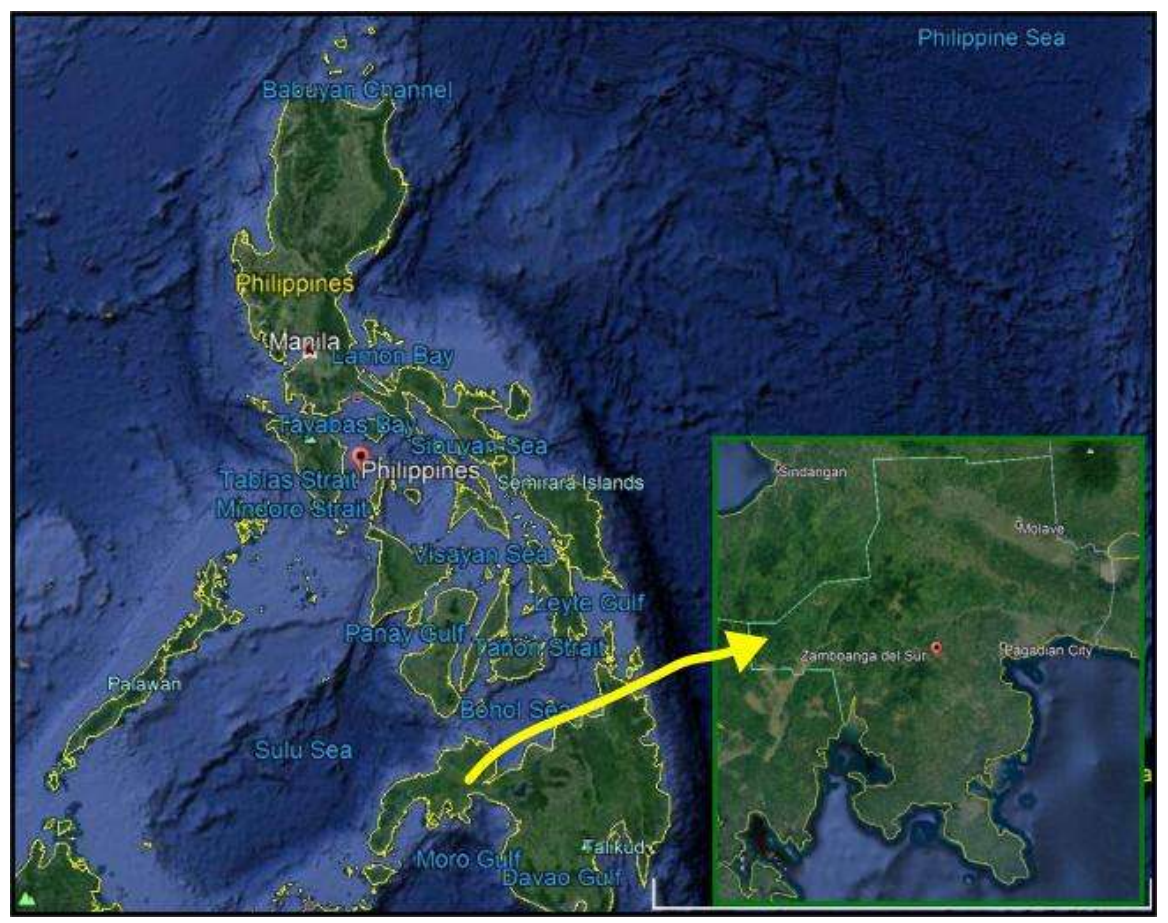

Figure 1. Map showing the locale of the study taken from the Google earth pro 2019.

\section{RESULTS AND DISCUSSION}

\section{A. Socio-demographic profile of the respondents}

Table 1 shows the age bracket, sex, civil status and educational attainment of the respondents. Out of 47 respondents, 28 are males and 19 are females. This simply shows that vermiculture is mostly done by men and it is still a masculine occupation, although, we can say that women are still engaged in vermicomposting because all operations are manageable.

On the age bracket of the respondents, many of them are in the age bracket of 46-55 with a total of 18 out of 47 respondents. It is followed by the age bracket of 56 and above with 13 or 26.67\%, 26-35 with 10 or $22.22 \%$ and $36-45$ with 6 or $13.33 \%$. These data show that both young and mature people are raising vermi. It doesn't matter whether young or old as long as they are motivated to do the job.

As to the civil status of the respondents, almost all of them are married to 44 out of 47 respondents while 2 are widows/widowers and only 1 is single. These data revealed that married people are more interested in vermiculture because they are matured enough to make their decision in choosing the suitable farming system

As to their educational attainment, most of them are college graduate with 24 out of 47 respondents, followed by high school level and college level at $15.91 \%$, elementary graduate at $6.82 \%$, high school graduate at $4.55 \%$ and elementary level at $2.27 \%$. This simply shows that vermiculture needs more technical knowledge, thus the interested growers are mostly professionals. However, there are also non-professionals who are interested in vermiculture as long as they are trained and knowledgeable in management and practices. 
Cebuano is the most dominant tribe who are engaged in vermiculture with 41 out of 47 or $87.23 \%$ followed by Ilonggo $8.51 \%$, and Waray and Boholano with $2.13 \%$ each. The data revealed that Cebuano is the dominant tribe of vermi raisers in the 9 municipalities surveyed.

For the household size, most of the respondents have 3-4 members as revealed by 31 out of 47 respondents. It is followed by 7 and above $17.02 \%, 5-6$ with $12.77 \%$ and $1-2$ with $4.26 \%$.

Table 1. Socio-demographic profile of the vermi raisers in Zamboanga del Sur, Philippines.

\begin{tabular}{|c|c|c|}
\hline Variables & Frequency & Percentage \\
\hline \multicolumn{3}{|l|}{ Age bracket } \\
\hline $26-35$ & 10 & 21.28 \\
\hline $36-45$ & 6 & 12.77 \\
\hline $46-55$ & 18 & 38.30 \\
\hline 56 and above & 13 & 27.66 \\
\hline \multicolumn{3}{|l|}{ Sex } \\
\hline Male & 28 & 68.29 \\
\hline Female & 19 & 46.34 \\
\hline \multicolumn{3}{|l|}{ Civil Status } \\
\hline Single & 1 & 2.13 \\
\hline Married & 44 & 93.62 \\
\hline Widow/widower & 2 & 4.26 \\
\hline \multicolumn{3}{|l|}{ Educational Attainment } \\
\hline Elementary level & 1 & 2.27 \\
\hline Elementary graduate & 3 & 6.82 \\
\hline High school level & 7 & 15.91 \\
\hline High school graduate & 2 & 4.55 \\
\hline College level & 7 & 15.91 \\
\hline College graduate & 24 & 54.55 \\
\hline \multicolumn{3}{|l|}{ Ethnic Group } \\
\hline Cebuano & 41 & 87.23 \\
\hline Ilonggo & 4 & 8.51 \\
\hline Waray & 1 & 2.13 \\
\hline Boholano & 1 & 2.13 \\
\hline \multicolumn{3}{|l|}{ Number of Siblings } \\
\hline $1-2$ & 2 & 4.26 \\
\hline $3-4$ & 31 & 65.96 \\
\hline $5-6$ & 6 & 12.77 \\
\hline 7 and above & 8 & 17.02 \\
\hline
\end{tabular}

Figure 2 shows the annual gross income of the respondents from all sources, membership of organizations, and land tenure relationship of the respondents. As shown in the table, most of them are having an annual gross income from all sources of $\square 50,000$ and above as revealed by 35 out of 47 respondents, followed in descending order by an annual income of 30,000-40,000 with 7 or $14.89 \%, 40,000-50,000$ with $6.38 \%$ and $20,000-30,000$ with $4.26 \%$. The data revealed that most of the vermin raisers in Zamboanga del Sur are earning an annual income from all sources of $\square 50,000$ and above. 


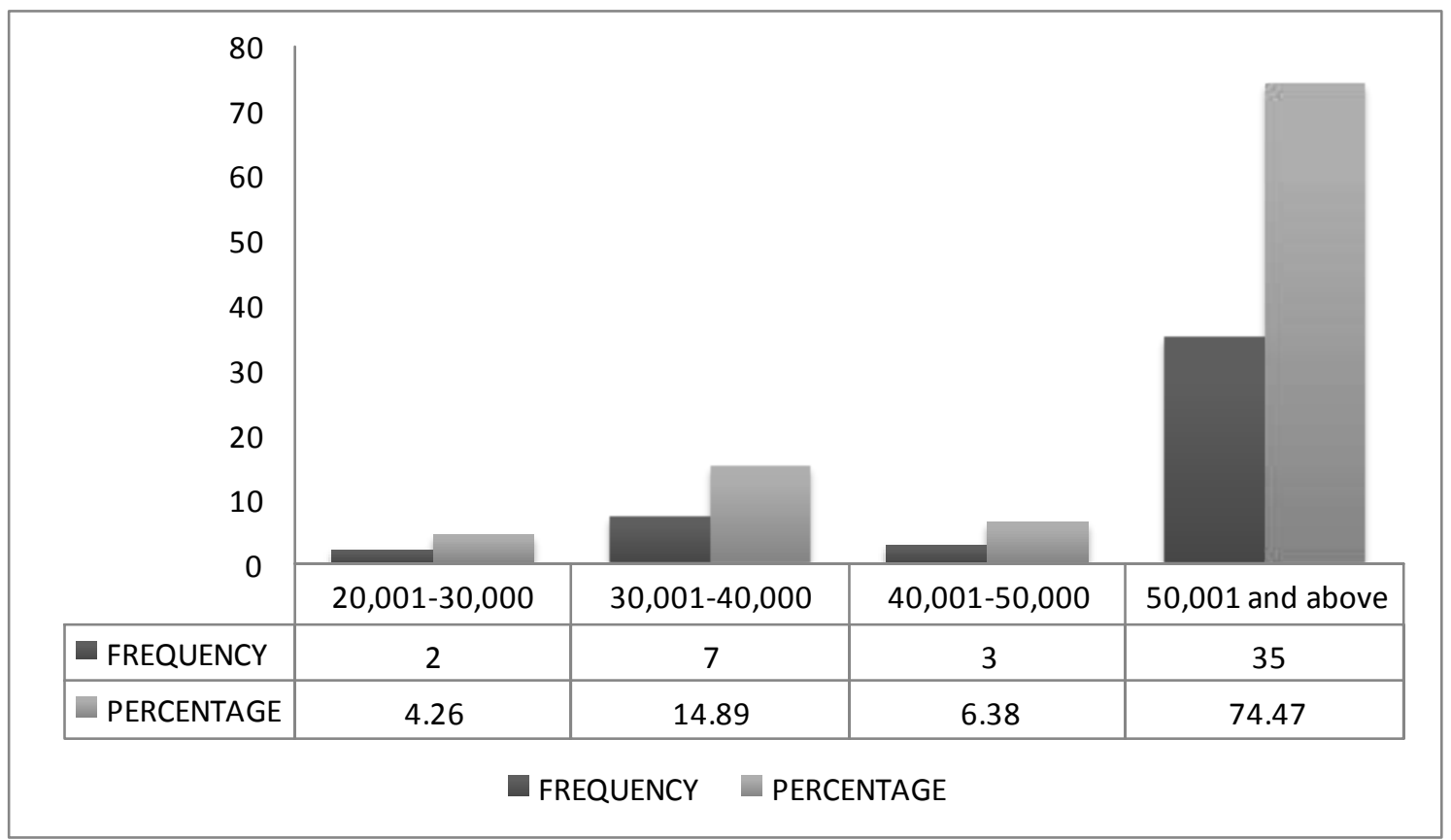

Fig. 2. Annual gross income of vermi raisers from all sources in Zamboanga del Sur.

Almost all of the respondents owned the land they tilled as revealed by 41 out of 47 respondents or $87.23 \%$ as shown in Figure 3. Only 5 out of 47 are tenants and 1 is the lessee. In Figure 4, many vermi raisers are beginners who adopted vermiculture for less than 1 year as revealed by 15 out of 47 respondents. Next in rank is $1-2$ years with a total of 11 or $23.40 \%$; followed by $4-5$ years with $17.02 \%$; $2-3$ years and 5 years and above with 6 or $12.77 \%$ and lastly, 3-4 years with 1 or $2.13 \%$.

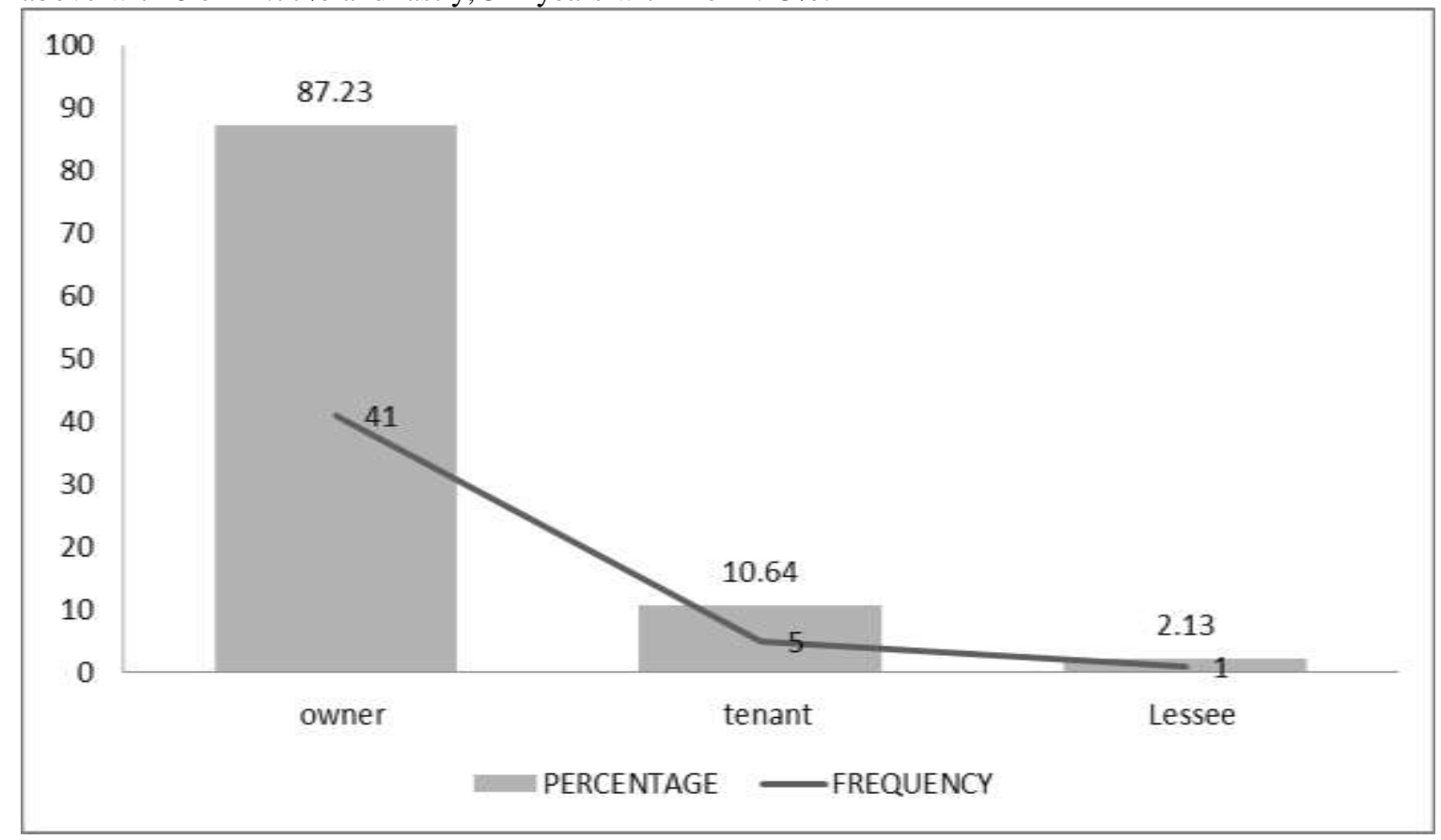

Fig. 3. Land tenure relations of the vermi raisers in Zamboanga del Sur, Philippines. 


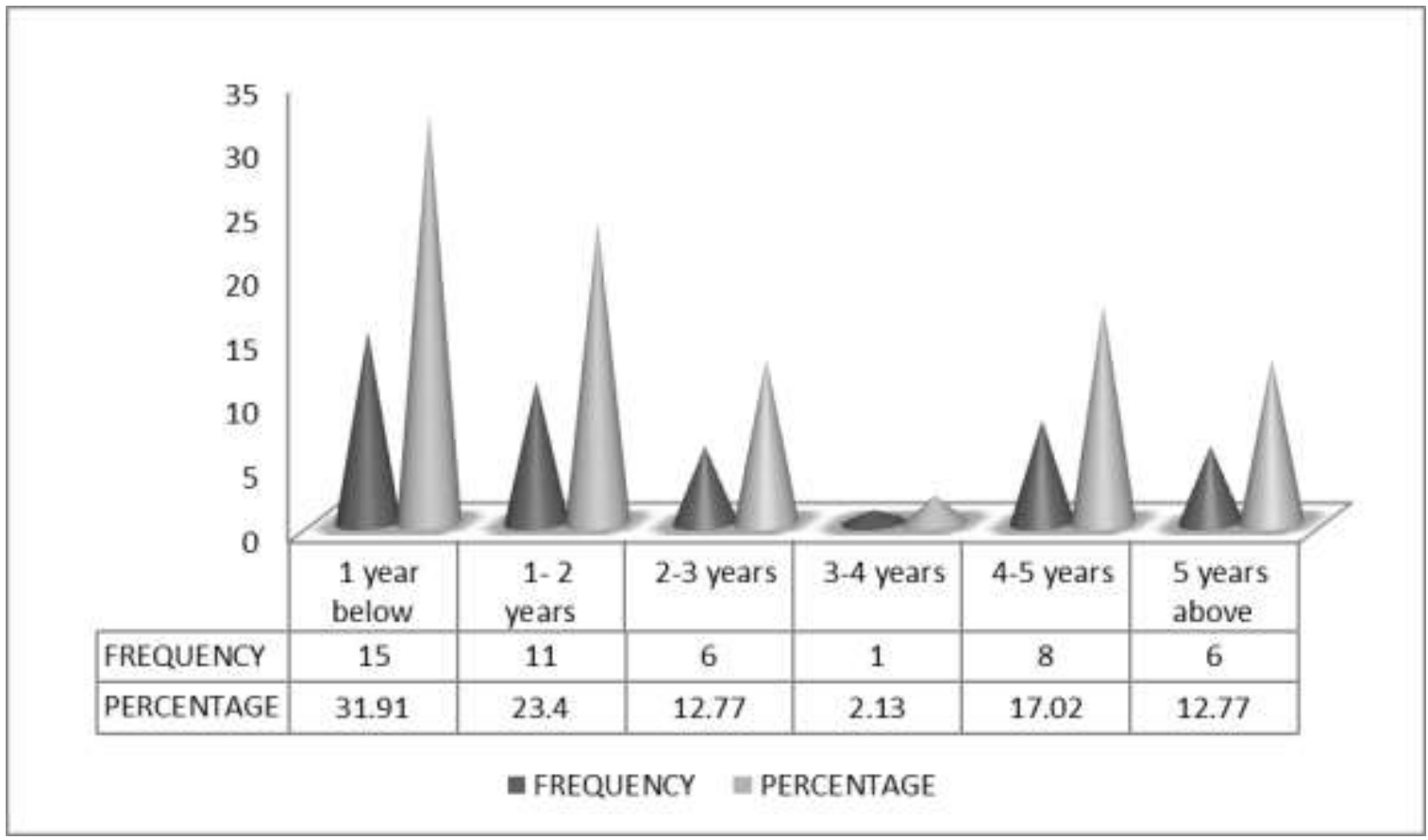

Fig. 4. Respondents' number of years in adopting vermiculture in Zamboanga del Sur, Philippines.

Table 2 presents the feeding materials used by the vermi raisers in Zamboanga del Sur. The rice straw $(60 \%)+$ kakawate $(5 \%)+$ manure $(35 \%)$ ranked number 1 as revealed by $40.43 \%$ (19 out of 47) respondents, closely followed by rice straw $(60 \%)+$ kakawate $(5 \%)+$ manure $(25 \%)+$ grasses $(5 \%)+$ banana peelings $(5 \%)$ with 14 or $29.79 \%$ (Figure 5); and rice straw $(70 \%)+$ kakawate $(5 \%)+$ manure $(15 \%)+$ Grasses $(5 \%)+$ jackfruit/pineapple $(5 \%)$ with 5 or $10.64 \%$. The data revealed that the choice of feeding materials vary from each other because it depends on its availability. The inclusion of 5\% banana, jackfruit, and pineapple peelings in the bedding materials improved the vermi population and were rated as high by the respondents.

Table 2. Feeding materials used by the vermi raisers and their rating on the vermi population as observed throughout the duration of production period in Zamboanga del Sur, Philippines.

\begin{tabular}{|c|c|c|c|}
\hline Feeding Materials & Frequency & Percentage & $\begin{array}{c}\text { Vermi } \\
\text { Population }\end{array}$ \\
\hline $\begin{array}{l}\text { 1. Rice straw }(60 \%)+\text { manure }(10 \%) \\
+ \text { saw dust }(20 \%)\end{array}$ & 2 & 4.26 & Moderately High \\
\hline $\begin{array}{ll}\text { 2. } & \text { Rice straw }(60 \%)+\text { kakawate }(5 \%) \\
& + \text { manure }(35 \%)\end{array}$ & 19 & 40.43 & Moderately High \\
\hline $\begin{array}{l}\text { 3. Rice straw }(70 \%)+\text { manure } \\
(25 \%)+\text { grasses }(5 \%)\end{array}$ & 1 & 2.13 & Moderately High \\
\hline $\begin{array}{ll}\text { 4. } & \text { Rice straw }(60 \%)+\text { kakawate }(5 \%) \\
+ \text { manure }(25 \%)+\text { grasses }(5 \%)+ \\
\text { banana peelings }(5 \%)\end{array}$ & 14 & 29.79 & High \\
\hline $\begin{array}{ll}\text { 5. } & \text { Rice straw }(70 \%)+\text { kakawate }(5 \%) \\
+ \text { manure }(15 \%)+\text { Grasses }(5 \%)+ \\
\text { jackfruit/pineapple }(5 \%)\end{array}$ & 5 & 10.64 & High \\
\hline
\end{tabular}




\begin{tabular}{|c|c|c|c|}
\hline 6. $\begin{array}{l}\text { Rice straw }(70 \%)+\text { kakawate }(5 \%) \\
+ \text { manure }(15 \%)+\text { grasses }(5 \%)+ \\
\text { vegetables }(5 \%)\end{array}$ & 1 & 2.13 & Moderately High \\
\hline $7 . \quad \begin{array}{l}\text { Kakawate }(5 \%)+\text { manure }(30 \%)+ \\
\text { grasses }(5 \%)+\text { banana stem \& } \\
\text { leaves }(60 \%)\end{array}$ & 2 & 4.26 & Moderately High \\
\hline $8 . \quad \begin{array}{l}\text { Saw dust }(60 \%)+\text { manure }(30 \%) \\
++ \text { kakawate }(5 \%)+\text { grasses }(5 \%)\end{array}$ & 2 & 4.26 & Loderately High \\
\hline $\begin{array}{l}\text { Rice straw }(70 \%)+\text { kakawate }(5 \%) \\
+ \text { manure }(10 \%)+\text { grasses }(5 \%)+ \\
\text { chicken dung }(10 \%)\end{array}$ & 1 & 2.13 & \\
\hline
\end{tabular}

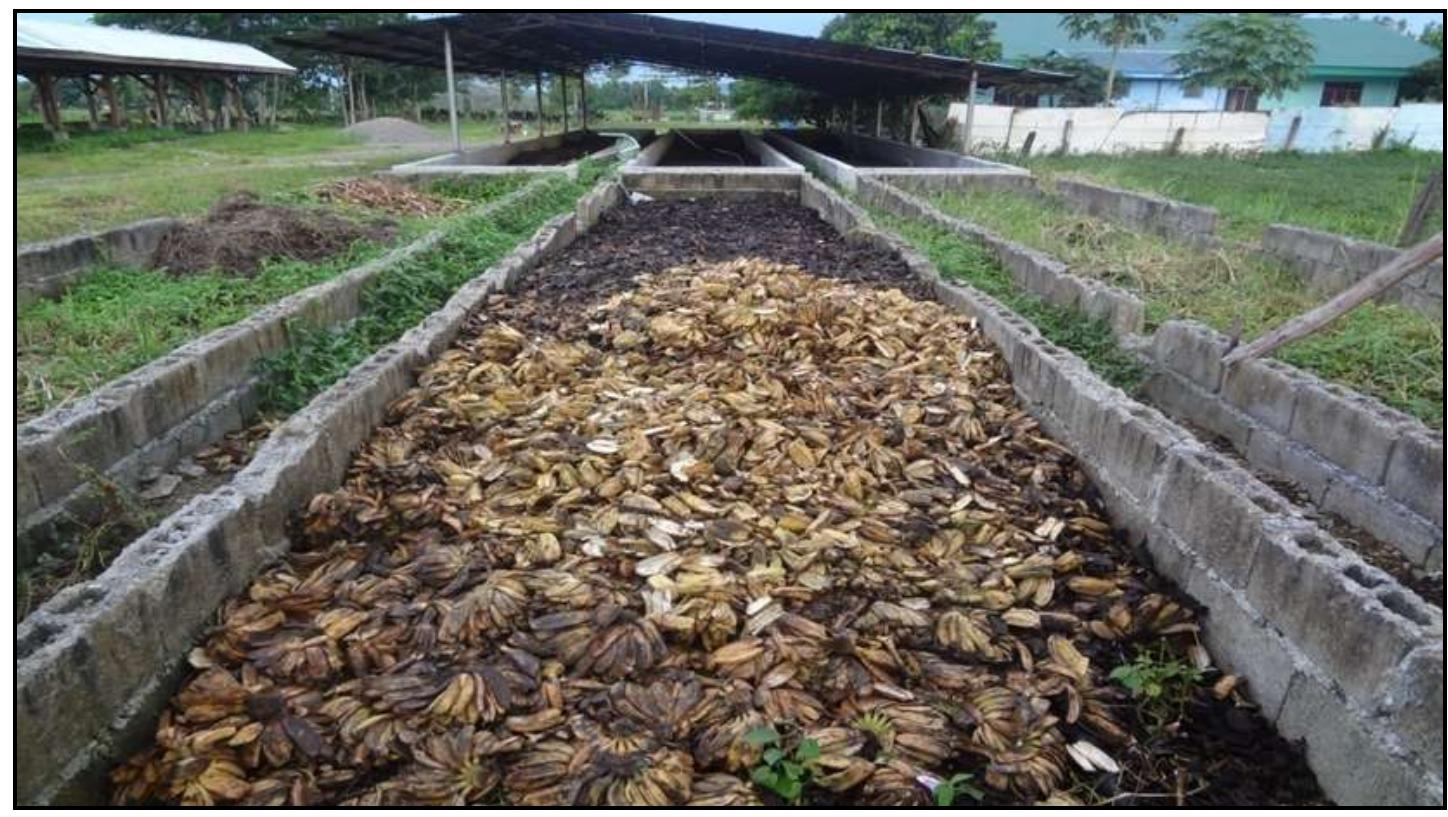

Fig. 5. Vermi fed with banana peelings in the vermiculture project of the Municipal Agriculture Office, Dumingag, Zamboanga del Sur, Philippines.

In the preparation of the feeding materials, the respondents chose the pre-decomposed feeding materials as revealed by 42 or $89.36 \%$, while 5 or $10.64 \%$ for not pre-decomposed as shown in Figure 6 . The data show that pre-decomposed feeding materials are the most suitable for vermi for rapid decomposition (Radhakrishnan \& Mahendran, 2008). In the study of (Gerlach, Russell, Jaeschke, \& Römbke, 2014), vermi fed preferably on the pre-decomposed materials. 


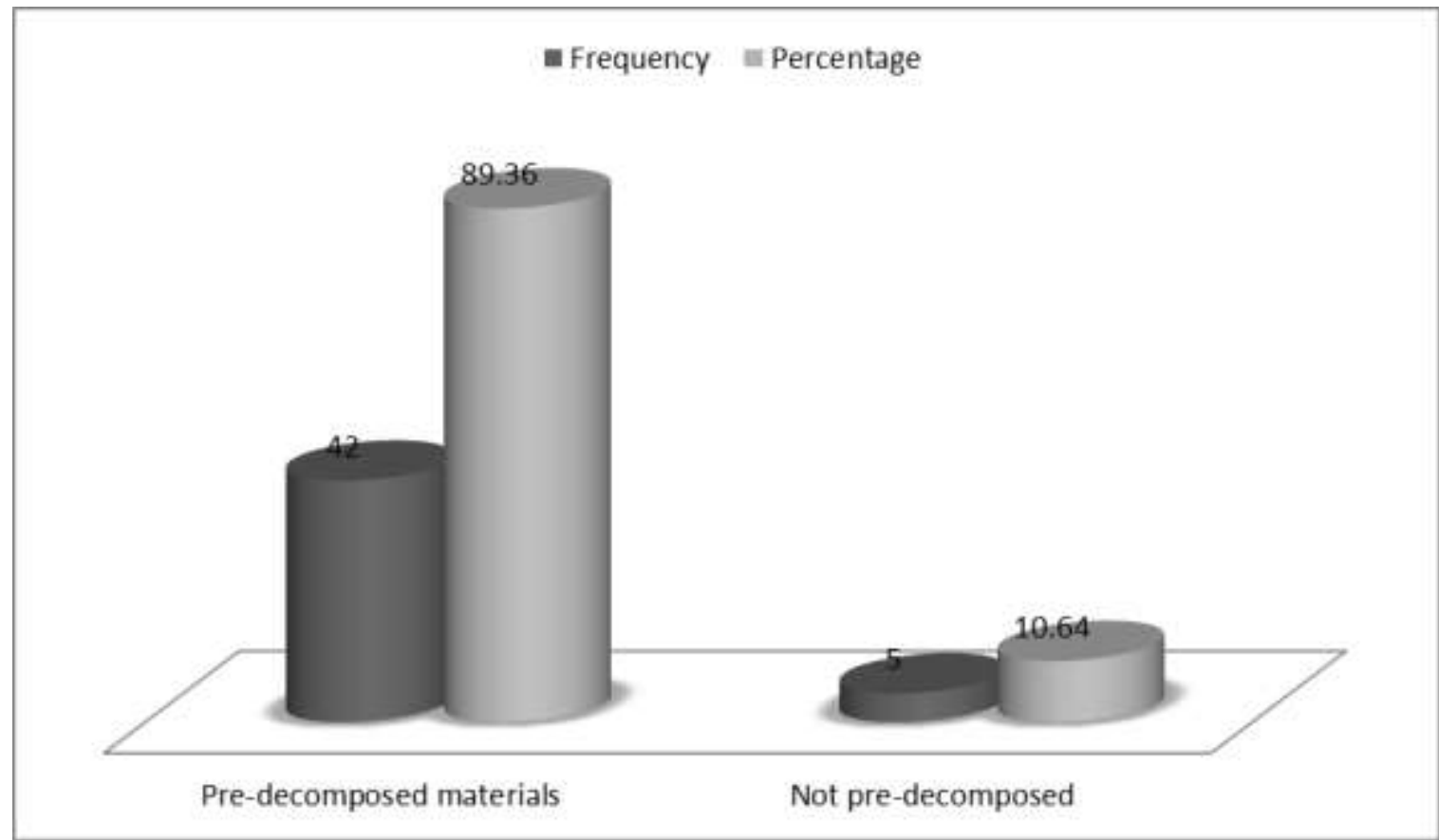

Fig. 6. Practices of the respondents in handling the feeding materials before introducing to the vermi bed.

For the water maintenance, the respondents preferred to water 3 times a week with 16 or $34.04 \%$, closely followed by once a day with 12 or $25.53 \%$, twice a week with 11 or $23.40 \%$ and once a week with 8 or $17.02 \%$ as shown in Figure 7. This simply reveals that all of the choices of the respondents are effective as long as the required moisture of $40-60 \%$ is met (R. P. Singh, Singh, Araujo, Ibrahim, \& Sulaiman, 2011) for efficient vermicomposting.

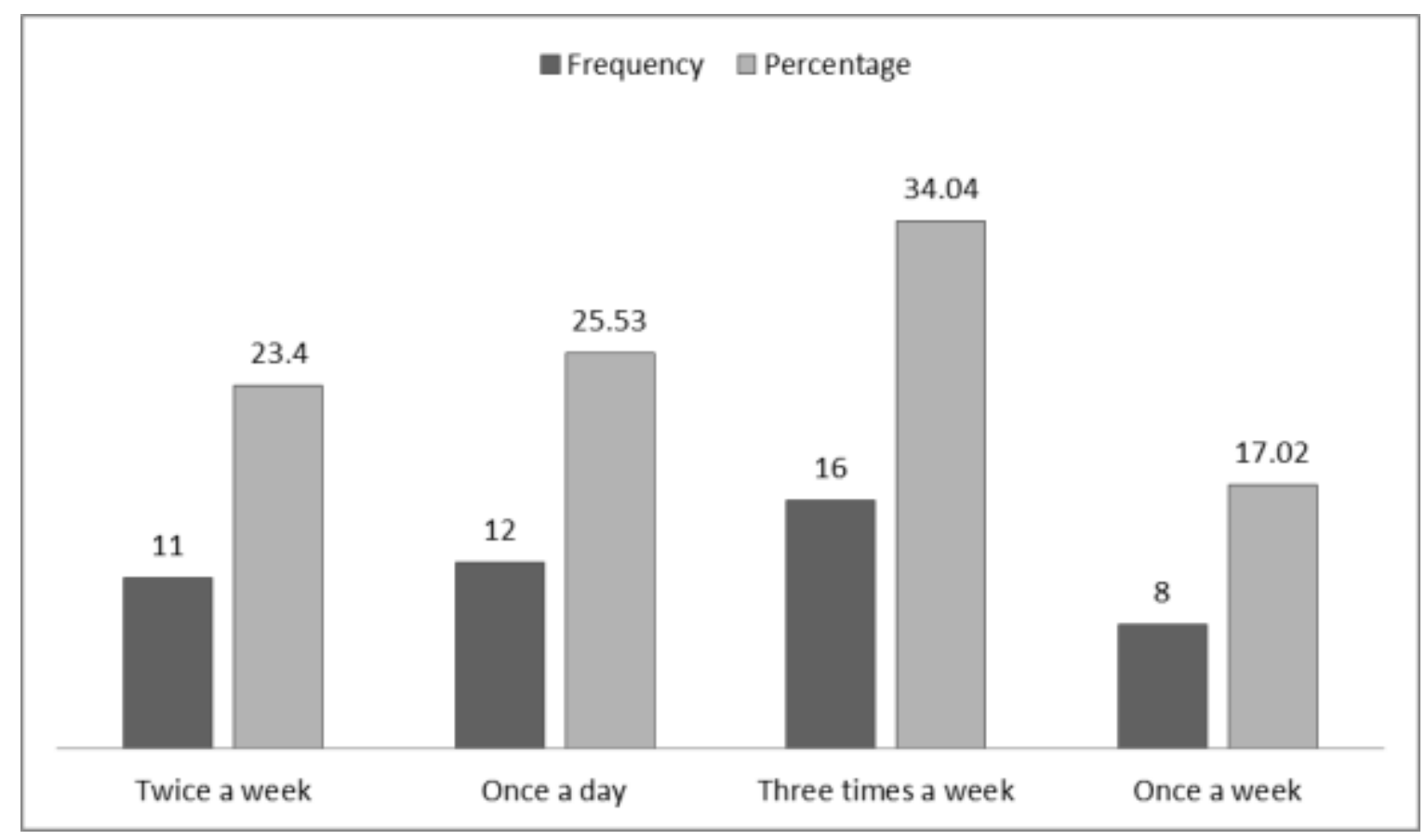

Fig. 7. Practices of the respondents in the water maintenance of the vermi bed. 
The data in Figure 8 revealed that $34.04 \%$ (16 out 47) have an average income per harvest of 5,000.00 and above, followed by 1,000 below and 1,001.00-2,000.00 both with $17.02 \% ; 2,001-3,000$ with 5 or $10.64 \%$, and 3,000-4,000 and 4,000-5,000 with 1 or $2.13 \%$. The data revealed that most of the respondents are earning 5,000 or more per harvest which indicates that there is money in vermiculture.

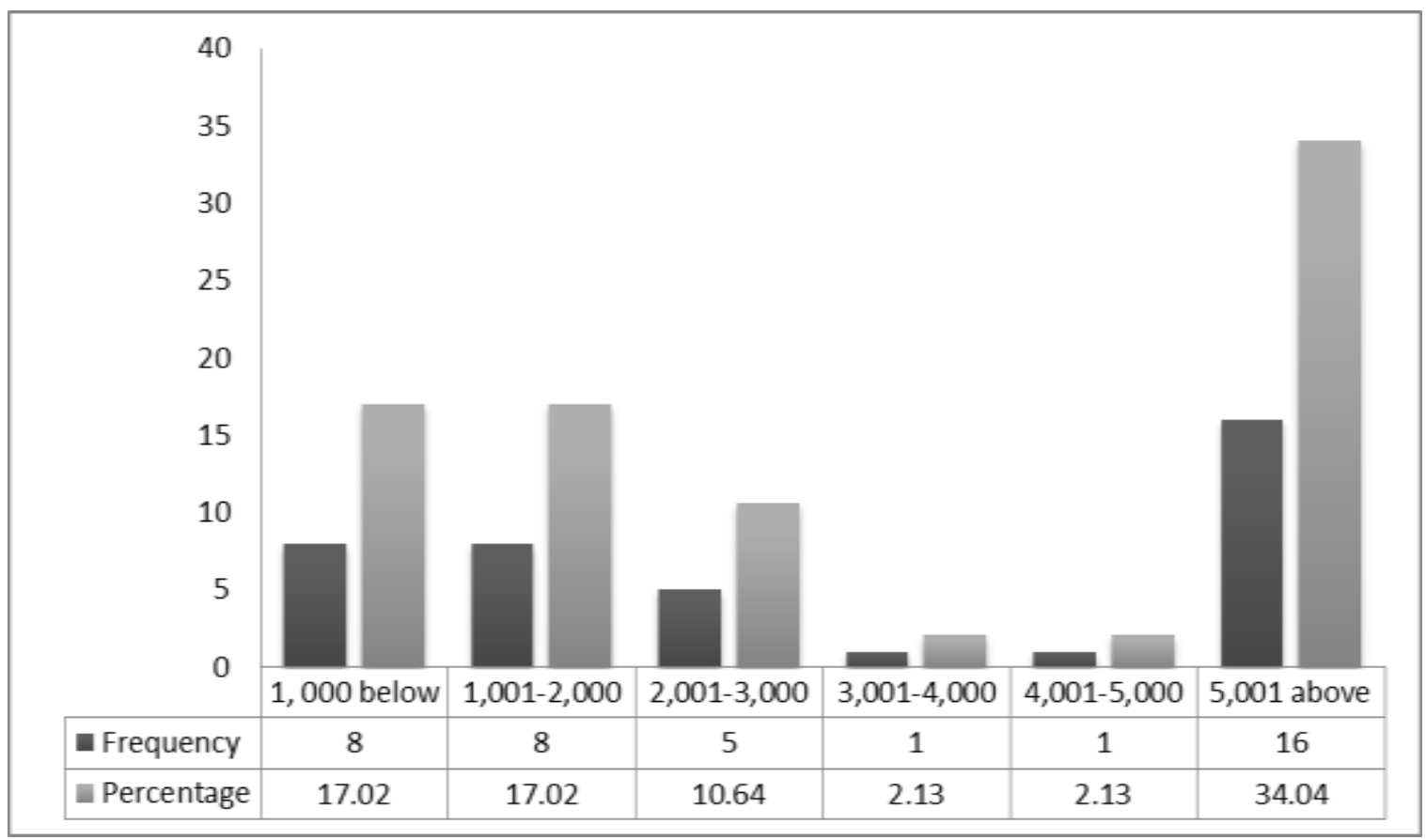

Fig. 8. The average income of the respondents per harvest of vermicompost in Zamboanga del Sur.

Table 3 shows the problems encountered by the vermi raisers. The respondents rated "not serious" on the problems such as less vermicast production, lack of source of feeding materials, difficulty in marketing, not profitable for business, not effective when used as organic fertilizer, lack of technical know-how, worms keep escaping, and the worm farm smells a bad/foul odor. Other problems like the higher cost of inputs and labor and pests' invasion during vermicast production were rated "serious" by the vermi raisers in Zamboanga del Sur. This simply means that most of the activities in vermiculture involve a higher cost of inputs and labor. Besides, there are also problems during the production of vermicast due to the invasion of some pests.

Table 3. Problems encountered by the respondents

\begin{tabular}{|c|c|c|}
\hline Problems Encountered & $\begin{array}{c}\text { Weighted Arithmetic } \\
\text { Mean }\end{array}$ & Description \\
\hline a. Less vermicast production & 1.64 & Not serious \\
\hline b. Lack of source of feeding materials & 1.68 & Not serious \\
\hline c. Difficulty in marketing & 1.70 & Not serious \\
\hline d. Not profitable for business & 1.90 & Not serious \\
\hline e. Not effective when used as organic fertilizer & 1.27 & Not serious \\
\hline f. Lack of technical know-how & 1.56 & Not serious \\
\hline g. The higher cost of inputs and labor & 4.0 & Serious \\
\hline h. Worms keep escaping & 1.53 & Not serious \\
\hline j. The worm farm smells a bad/foul odor & 1.26 & Not serious \\
\hline k. Pests invasion during vermicast production & 4.0 & Serious \\
\hline
\end{tabular}

Table 4 presents the suggested solutions to the problems encountered by the respondents. As shown in the table, seek assistance from the Municipal Agriculture Office (MAO), Department of Science and Technology (DOST), and other extensionists, cover the bed with polyethylene, sacks, plywood, canvass and galvanized iron, and use pre-decomposed feeding materials are the most effective solutions revealed by the 
respondents. Results revealed that the suggested solutions are very useful in solving their problems and in sustaining the vermicomposting project.

Table 4. Suggested solutions to the problems encountered by the respondents

\begin{tabular}{|l|c|c|}
\hline \multicolumn{1}{|c|}{ Solutions } & $\begin{array}{c}\text { Weighted } \\
\text { Arithmetic Mean }\end{array}$ & Description \\
\hline a. Seek assistance from MAO, DOST and other extensionists & 4.52 & Effective \\
\hline b. Read hand-outs and other reading materials & 3.46 & Less effective \\
\hline c. Access technology on the internet & 2.64 & Less effective \\
\hline $\begin{array}{l}\text { d. Cover the bed with dark cellophane, sacks, plywood and } \\
\text { galvanized iron to enhance the eating ability of vermi. }\end{array}$ & 4.25 & Effective \\
\hline e. Purchase more worms/vermi & 2.44 & Less effective \\
\hline $\begin{array}{l}\text { f. Use pre-decomposed feeding materials to avoid pathogenic } \\
\text { bacteria }\end{array}$ & 4.62 & Effective \\
\hline
\end{tabular}

\section{IV.CONCLUSION AND RECOMMENDATIONS}

Most of the respondents are males, with an age bracket of 46-55, married, Cebuano, Catholic, and college graduate. They preferred to use rice straw, kakawate, and manure as feeding materials. An inclusion of $5 \%$ banana, jackfruit and banana peelings in the substrate increased the vermi population. The respondents used pre-decomposed feeding materials. Majority of the respondents watered their vermiculture 3 times a week or more with adequate moisture of $40 \%-60 \%$. Vermiculture is threatened by many problems like the higher cost of inputs and labor, and pest invasion during vermicast production. Despite to the problems encountered by the respondents, there are also solutions to the problems like: cover the bed with sacks, plywood, galvanized iron and canvass, gather \& stock plenty of feeding materials (rice straw, manures), use pre-decomposed feeding materials like banana leaves or stems \& other grasses, and seek assistance from the agriculturists. Based on the results, it is recommended that the local government units through the municipal agriculture office should lead the advocacy in promoting vermiculture technology, and establish a strong bonding relationship with the vermi raisers in their locality by tapping potential buyers and market opportunity. The vermi raisers must utilize available resources of feeding materials within their vicinity, encourage to use pre-decomposed feeding materials to avoid pathogen, cover the worm bed with plywood, galvanized iron, and canvass to enhance the eating ability of worms, and maintain adequate amount of moisture (40\%-60\%) to avoid the worms from escaping. An inclusion of 5\% jackfruit, banana, pineapple, and other fruits peelings in the vermi bed is also highly recommended to increase its population.

\section{ACKNOWLEDGMENT}

This study was realized through the funding and support of Dr. Moises Glenn G. Tangalin. The authors are also indebted to the Zamboanga del Sur Provincial Government College, Aurora, Zamboanga del Sur; and the J.H. Cerilles State College - Dumingag Campus, Dumingag, Zamboanga del Sur for the support in the completion of this research activity.

\section{REFERENCES}

[1] Aalok, A., Tripathi, A. K., \& Soni, P. (2008). Vermicomposting: A better option for organic solid waste management. Journal of Human Ecology, 24(1), 59-64.

[2] Adorada, J. L. (2008). Assessment of vermicomposting as a waste management technology and a livelihood alternative in the Philippines. Journal of Environmental Science and Management, 10(2).

[3] Altieri, M. A., \& Koohafkan, P. (2008). Enduring farms: Climate change, smallholders and traditional farming communities (Vol. 6). Third World Network (TWN) Penang.

[4] Carvalho, F. P. (2017). Pesticides, environment, and food safety. Food and Energy Security, 6(2), 48-60.

[5] Gerlach, A., Russell, D. J., Jaeschke, B., \& Römbke, J. (2014). Feeding preferences of native terrestrial isopod species (Oniscoidea, Isopoda) for native and introduced leaf litter. Applied Soil Ecology, 83, 95-100. 
[6] Guerrero III, R. D. (2010). Vermicompost production and its use for crop production in the Philippines. International Journal of Global Environmental Issues, 10(3-4), 378-383.

[7] Karmegam, N., \& Daniel, T. (2009). Effect of application of vermicasts as layering media for an ornamental plant Codiaeum variegatum (L.) B1. Dyn Soil Dyn Plant, 3, 100-104.

[8] Radhakrishnan, B., \& Mahendran, P. (2008). Effect of different bedding materials available in tea plantations on the quality of vermicompost. Newsletter-UPASI Tea Research Foundation, 18(1).

[9] Satchell, J. (2012). Earthworm ecology: From Darwin to vermiculture. Springer Science \& Business Media.

[10] Sharma, A., Sharma, R., Arora, A., Shah, R., Singh, A., Pranaw, K., \& Nain, L. (2014). Insights into rapid composting of paddy straw augmented with efficient microorganism consortium. International Journal of Recycling of Organic Waste in Agriculture, 3(2), 54.

[11] Singh, R., Kapoor, V., \& Kumar, V. (2012). Utilization of agro-industrial wastes for the simultaneous production of amylase and xylanase by thermophilic actinomycetes. Brazilian Journal of Microbiology, 43(4), 1545-1552.

[12] Singh, R. P., Singh, P., Araujo, A. S., Ibrahim, M. H., \& Sulaiman, O. (2011). Management of urban solid waste: Vermicomposting a sustainable option. Resources, Conservation and Recycling, 55(7), 719-729.

[13] Singh, S., \& Nain, L. (2014). Microorganisms in the conversion of agricultural wastes to compost. Proc Indian Natn Sci Acad, 80, $473-481$. 